\title{
Copëza malli, të një malli të pafund
}

\author{
(për librin Copëza malli, Kujtime, rrëfime, të Bim Daklit)
}

Tomorr Plangarica

\section{Leximi i Kujtimeve, i ngjashëm me përjetimet përgjatë spektakleve në të cilat është pak të jemi thjesht spektatorë}

Kujtimet dhe rrëfimet e jetës janë përgjithësisht udhëtime të bukura në hapësirat herë më të ngushta e herë më të gjera nëpër të cilat individi është endur përgjatë jetës së tij; udhëtime në ato hapësira prej të cilave ai vetë ka marrë nxitje, emocione, mbresa e shtytje që i mbeten të pashlyeshme në kujtesë, e si të tilla, në një kohë të mëvonshme kërkojnë të dalin prej kujtesës për t'u pronësuar në formën e copëzave të mallit edhe nga të tjerë, familjarë a të afërt të individit, bashkëkohës a pasues në kohë të tij: si të tilla, ato mund të ndjellin të njëjtat ndjesi edhe te të tjerët; janë mesazhe të cilat mund të rrinë disi ngushtë thjesht në kujtesën e një individi; jehona e tyre kërkon hapësirë më të gjerë për t’u vlerësuar për brendinë e vlerën që ato përçojnë. Ndaj, edhe pse lindin e përftohen të lidhura me një individ, me një mjedis familjar a rreth më të ngushtë shoqëror, ato jo pak herë tentojnë dhe pronësohen nga një numër shumë më i gjerë kundruesish, dëgjuesish, e në rastin më të mirë, lexuesish.

Marrja në dorë e librit me kujtime e rrëfime Copëza malli, i shkruar nga Bim Dakli, leximi dhe endja bashkë me rrëfyesin në hapësira të gjera ndodhish e përfytyrimesh në kohë e vende të ndryshme, të njohura a jo prej nesh, na ndihmon të njohim e të zbulojmë gjithashtu edhe te vetja diçka të lidhur me to, shumëçka që nxitet prej tyre; na ndihmon të përftojmë së bashku me të ndjesi që mund të na çojnë herë në fëmijërinë tonë të hershme, herë në rini ; na ndihmon të endemi po ashtu edhe në hapësira ku kanë marrë 
kuptim tregues të rëndësishëm të qenies sonë, të përkatësisë sonë, edhe pse ato hapësira mund të mos jenë të njëjtat me ato të rrëfyesit ; e në këtë rast, kjo marrëdhënie u ngjan raporteve që krijojmë me ndodhitë në një shfaqje teatrale, ku edhe pse në vendin e spektatorit, ndjehemi gjithsesi, më së paku, dëshmitarë e përjetues të ngjarjes e veprimeve ; e hera-herës, pse jo, edhe përjetues edhe më shumë se vetë aktorët në skenë. Vendet e zhvillimit të veprimit, të përqendruara kryesisht në Elbasan e Tiranë, jo pak herë edhe në vise të tjera deri në Itali, Austri por edhe më gjerë, shndërrohen natyrshëm në hapësira në të cilat lëviz lirshëm rrëfyesi, por edhe ne të tjerët, duke përftuar një simbolikë të vlefshme edhe për sot.

Në një kuptim më të gjerë, përgjatë leximit i përafrohemi natyrshëm metaforës që e parakupton jetën si një skenë ku luhen fate njerëzish pranë a larg nesh, por gjithsesi, në një mënyrë a një tjetër, të lidhura me ne. Kujtimet e rrëfimet e Daklit na nxisin drejt përforcimit të idesë se jeta e njeriut, e individit a individëve përkryhet në një skenë ku përkojnë e përballen fate individësh a grupesh, në mizanskena, në sfonde e dekore nga më të larmishmet, në kahje e detyrime po ashtu të paparashikueshme, ku individit i bie hera-herës të luajë protagonistin, siç, më së shumti, të mos ketë aspak rol të ndjeshëm aty. Është një formë e komunikimit e cila, megjithëse i ka fillesat mijëra vjet më parë, vijon të mbetet tërheqëse, sepse bart vetvetishëm kalimin nga vetjakja te socialja, nga ajo çka meriton të mbetet tejet subjektive dhe e brendshme, në atë çka bëhet karakterizuese për një komunitet a bashkësi.

Në fakt, qysh se njeriu u bë i ndërgjegjshëm për protagonizmin e tij, e gjeti mundësinë t’i afrohet këtij spektakli e ta amplifikojë atë me forma të artit ; fillimisht më poetike, por më tej edhe më konkrete: qysh në antikitet, madje, duke mos u kënaqur vetëm me epopetë a këngëtimin e bëmave, por duke kërkuar edhe analogjitë e shfaqura në formën e dramatikes - të tragjedive a komedive.

Por edhe pse heroizimi i raporteve mes njerëzve përftonte joshje, ndihmonte më së shumti edhe për përsosje dhe rregullim social, fatet e pafundme të individëve në skenën e jetës, me mizanskenat po ashtu në pafundësi të shfaqjes së tyre, i lanë shkallë-shkallë hapësirë edhe një forme tjetër të komunikimit publik, që nuk kishte nevojë të heroizonte, por thjesht të përshkruante protagonistë pa protagonizëm, përditshmërinë e tyre që ngjall emocion, respekt e mall për atë çka përfaqëson; mesazhet zbritën në këtë mënyrë prej lartësive të hyjnores e heroikes në mjedise më tokësore, madje tejet tokësore ; lindën në këtë mënyrë kujtimet, rrëfimet e jetës, e më tej, të joshur sërish nga protagonizmi, autobiografitë, biografitë, etj. 


\section{Albanon}

Gjithsesi, mbeti ky lloj i shkrimësisë kryesisht si një formë e intimitetit në komunikim, si hapësirë e afeksionit, përmallimit, dashurisë...; mbeti ky lloj i shkrimësisë, hapësira ku individi nuk e synon, nuk e mëton funksionin e qenies ngulmuese sociale, por është lexuesi ai që më së shumti ia atribuon edhe këtë funksion përgjatë ri-ndërtimit të domethënieve, duke ia zgjeruar në këtë mënyrë vlerën mesazheve të përçuara. Ndaj rrëfimtari nuk është thjesht një individ, por shndërrohet në një qenie të socializuar, një "person" në kuptimin që i jep termit Hannah Arend-i; teksti si i tillë shihet gjithnjë e më shumë jo thjesht si mesazh që pasqyron një të shkuar, copëza jete në atë të shkuar, por edhe si një e tashme e së shkuarës, nëse do të shpreheshim me termat e shën Augustin-it; dhe në këtë kontekst, roli i lexuesit po ashtu është ridimensionuar, ai nuk është thjesht shijues historish, por ri-interpretues dhe bashkëkrijues i mesazhit.

Shkrimi i rrëfimeve, përveçse një nxitje e brendshme, produkt i një aftësie të lindur a të kultivuar, është edhe përmbushje e këtij komunikimi social me të tjerët, është edhe përmbushje e këtij funksioni, sado intime, thjesht vetjake a familjare qofshin kujtimet, sepse prej treguesve të ndryshëm të biografizmit, burojnë natyrshëm, aktualizohen e përshtaten edhe të dhëna për ritualet tona, sjelljet, kodet e botëve sociale e të përkatësisë sonë.

Për më tepër, shkrimi i kujtimeve në moshë të mbrame (siç është edhe rasti i Bim Daklit) dhe botimi i tyre është një formë bashkëbisedimi plotësuese për shkruesin/rrëfimtarin që kërkon të sfidojë vitet dhe zgjerojë rrethin e bashkëbiseduesve, duke u prirur të gjejë në komunikim bashkëbisedues që po ashtu nisen nga po e njëjta sfidë, pavarësisht se mund të vendosen në skajin tjetër të segmentit kohë : kemi një endje përfytyrimesh e ripërjetimesh nga rrëfyesi në hapësira në të cilat ai rishkel i përmalluar me barrën e viteve mbi shpinë ; dhe një ri-ndërtim të domethënieve të mesazheve nga një lexues i moshave të ndryshme (ndaj edhe ai i pamoshë), që shkel në po ato hapësira dhe kënaqet me përmallimin e rrëfyesit, duke përftuar po ashtu edhe ai mall për atë çka mund të njohë, por sidomos mall, dhimbje, kënaqësi a entuziazëm për ato çka përjeton duke lexuar, por nuk i ka njohur dhe s'mund t’i njohë, por që i interesojnë, edhe pse s’janë pjesë e nevojave utilitare të përditshmërisë së tij.

E në këtë mënyrë shpërfaqet natyrshëm edhe funksioni më i vërtetë i vetë rrëfimeve që nuk është dhënia me sa më tepër objektivitet i ngjarjeve reale që përbëjnë historinë a rrëfimin e subjektit, të tilla siç ato janë zhvilluar në ato çaste, por të dalë në pah raporti që ndërmerr subjekti sot me këto 
ngjarje. Është më tepër kuptimi që subjekti i atribuon këtyre ngjarjeve që na interesojnë neve sot, sesa ngjarjet në vetvete. Dhe ky funksion përftohet ngaqë përgjithësisht nevoja për rrëfim lind kur qenia/vetëqenia është e përmbushur në aspektin social, ndaj kërkon të kompensojë edhe diçka tjetër, një përmasë tjetër që e vëren të pranishme te vetjakja, individualja, atje larg, përgjithësisht në vitet e fëmijërisë a rinisë, kur përplasjet, e përgjithësisht brutaliteti i sociales ende nuk është shfaqur. Është një prirje për të plotësuar realitetin e vrazhdë të jetës sociale, të rrugës së përftimit të qenies sociale, me shfaqjet e profilet më romantike të vetes në moshën e pafajësisë, a fajësive të pafaj.

\section{Veçanërisht në periudha ndryshimesh sociale e politike, kriza e modelit na shtyn drejt kujtimeve, drejt kërkimit të vlerave dhe virtyteve që përftojnë përkatësinë tonë}

Shfaqet më ngulmues ky lloj i shkrimësisë sidomos në periudha ndryshimesh sociale e politike, kur shtrohet natyrshëm nevoja e modeleve që përçojnë vlera në raport me koncepte a institucione të tilla si familja, tradita, kultura, kujtesa historike, etj.

Shfaqen të vlerta nga ky këndvështrim rrëfimet e Daklit, ndërsa na mungoi përgjithësisht një periudhë serioze reflektimi dhe iluminimi fill pas shndërrimeve në vitet nëntëdhjetë në lidhje me të kuptuarit më të thellë dhe realist të marrëdhënieve me tjetrin, me familjen, pronën, komunitetin dhe përkatësinë tonë në përgjithësi. Rrëfimet si këto të Daklit ofrojnë projeksione të besueshme të respektit për familjen dhe mjedisin qytetar, ku mëkohen e kultivohen në vijimësi vlerat e tiparet e përkatësisë sonë.

Ndjenja e përkatësisë mund të mos zbehet a mpaket, edhe nëse jeta mund të të çojë a përplasë në vise të tjera, qofshin ato edhe më të kultivuara, kur ajo buron natyrshëm nga një mjedis me norma të mirëpërcaktuara, që të ngjall e imponon respekt dhe të mundëson dinjitet, pavarësisht mirëqenies a përmasave modeste të saj në atë mjedis; kur buron nga familja tek e cila nis të ngjizet më së pari fryma e parë e humanizmit dhe ndjesive të brishta; kur buron nga kujtimet e përmallimet e fëmijërisë, që nuk kërkon luks e pasuri, por thjesht të gëzojë pafajshmërinë e saj; nga shtëpia, që edhe e vogël dhe e pamobiluar qoftë, në sajë të harmonisë familjare, merr përmasat e shtëpisë së ëndrrave ; nga kopshti prej të cilit mund të mos zbehet kujtimi për asnjërën prej pemëve, ngjyrën e gjetheve, petaleve, madje të mbetet i ngulitur në mendje edhe pamja trishtuese e trungut të zhveshur në stinën e ftohtë; nga 


\section{Albanon}

rrugicat e vogla, të ngushta, të shtrembra jo pak herë, por që bartin e ruajnë histori e fate njerëzish; nga kanalet a remat përbri, ku herë kridhesh si fëmijë për t'u larë, por më së shumti kotesh e mrekullohesh prej pilivesave e fluturave krahëshkruara që vallëzojnë paprerë aty pranë; nga portokallat dhe ullinjtë, hija e të cilëve duket si bekim për çdo prag shtëpie e çdo ngastër familjare në ullishtë, për t'u ndalur veçanërisht te rrapat, madhështia e të cilëve mbetet si pikë reference gjithnjë e dukshme në kujtime, se vetë ajo pemë madhështore vjen prej historisë dhe me histori; e për më tepër, çdonjëra prej pemëve ka edhe historinë e veçantë në kujtesën e çdonjërit, e më së shumti në kujtesën e një popullsie, një qyteti. Siç na dëshmon Herodoti, sakrifica për ta ruajtur me çdo kusht të pacënuar atë pemë madhështore vjen qysh prej lashtësisë; a mos vjen sërish prej asaj kohe të largët edhe sakrifica tronditëse e pranishme në kujtimet e Daklit (të priten të dy trupat, $i$ imi dhe i pemës, ose asnjëri kumbon si e pakohë thirrja e adresuar e shpirtit të një piktori, mik i ngushtë $i$ rrëfyesit?!). A është kjo sakrifica kur Sersi vendosi ta ruajë atë pemë, mijëra vjet më parë, apo është ndodhi e kohëve moderne, me patosin e pazbehur që mundëson përftimin e tipareve të përkatësisë së njeriut të lidhur me natyrën, me vendin, me traditën, kujtesën historike të mjedisit ku vepron?

Dhe siç kërkon e rrëmon në kujtimet e tij, po aq natyrshëm Dakli kërkon edhe jashtë tyre, në kujtesën e qytetit; por vë re që kujtesa e tij vuan nga amnezia; makthe e zjarrmi duhet të ketë kaluar trupi i qytetit ndër vite; gjurmë lëndimesh janë të pranishme; por edhe gjurmë përkujdesjesh, gjithsesi... A mund ta shërojmë këtë amnezi? Kujtimet dhe rrëfimet si këto të Daklit janë ndër format që priren ta ngushtojnë sadopak përmasën e asaj amnezie, të shëndoshin ndonjë prej lëndimeve të shkaktuara.

Natyrshëm teksti bëhet i afërt edhe për lexuesin e sotëm që kërkon t’i njohë ato vlera; lexuesi mund të gjejë te rrëfimet e Daklit jo pak herë të njëjtat pikëvështrime si edhe ato të babait e gjyshit të tij, të njëjtin mall a përmallim që i ishte mëkuar në rrëfimet herë të kursyera e herë të pakursyera të prindërve a familjarëve; e më së fundi, lexuesit ia blatojnë edhe Daklit këtë status.

Dhe në këto raste nuk ka më rëndësi nëse dashuria e shfaqur është për vendlindjen e Daklit apo për çdo vend tjetër ku ke lindur; është për çdo vend që mbetet i dashur pikërisht se ti krijon një marrëdhënie të caktuar me të. Është një raport aspak i kaluar në kohë, madje gjithnjë tejet i kohës.

Madje dashuria e Daklit për vendlindjen është ndër ato raste kur largimi prej saj nuk ta mpak aspak përmasën e asaj ndjenje ; por veçse të jep më shumë mundësinë të qartësosh raportin tënd me të, kur ajo distancë ta bën edhe më 
imponuese të kërkosh e gjesh ato rrënjë, kur malli të nxit ato energji pozitive tejet humane që mundet të zbehen e zhbëhen hera-herës nën peshën e rëndë të halleve e përditshmërisë rutinë atje, në vendlindje; dhe ajo distancë mund të t’i përftojë qëndrimet hera-herës shumë të përmalluara e idilike, e herë të tjera tejet kritike e ndoshta jo në hullinë e përftuar ndërkohë si bindje, modë a mënyrë të menduari atje, në lidhje me ngjarje, fakte a personazhe; gjithsesi, përftohet natyrshëm një variant alternativ në vlerësim; ndaj lexuesi i sotëm, sidomos ai i lidhur me qytetin e Elbasanit a Tiranës, e ka këtë libër si vijim të bashkëbisedimit me babain a nënën, gjyshin a gjyshen, e ka autorin tashmë pjesë të të afërmve të tij, edhe kur ai është një zë ndryshe.

\section{Që ndjenja e përkatësisë familjare e ndjenja e pronës të mos konsiderohen më herezi, është e dobishme të jepen modele të respektit për të}

Në vitet e pasnëntëdhjetës, në ngutjen e natyrshme për t’i kapërcyer kufijtë ngushtues të moralit të imponuar përmes modelit të "njeriut të ri”, e ndërgjegjësuam jo aq sa duhet faktin se drejt së ardhmes, drejt një bote tashmë pa kufizime jemi më të denjë kur bartim edhe vlerat më të mira të kultivuara në brezni në mjedisin familjar e atë qytetar, vlera që na shfaqen si tregues domethënës të përkatësisë sonë; e për ta bartur atë përmasë, duhen modelet që na ndihmojnë ta përftojmë atë; ajo ngutje e fillimit, pa e përftuar edhe këtë përmasë, parametrat e së cilës kanë të brendashkruar ndjenjën e respektit e dashurisë për familjen e qytetarinë, ndjenjën e adhurimit për natyrën dhe mjedisin ku rritesh e formohesh, po na vonon tragjikisht në lëvizjen tonë drejt së ardhmes. Në atë pjesë të përkatësisë që lidhet me vendlindjen, familjen, qytetarinë e mjedisin, kujtimet e Daklit mund të marrin natyrshëm status reference në profile të ndryshme përvoje; dhe është një domethënie ngulmuese që përftohet, duke i sfiduar largësitë ndaj objektit të dashuruar ; duke i dhënë edhe një tjetër përmasë vetë konceptit të përkatësisë : individi a grupi social i përket jo thjesht asaj që përcaktohet nga qoka hapësinore dhe kohore ndaj të cilave ti dhe paraardhësit e tu s'kanë meritë tjetër veçse kanë rastisur aty të pranishëm, por, më së tepërmi, përcaktohet prej asaj çka është kultivuar në ato mjedise si vlerë, si frymë, të cilat ti i ke përvetësuar vetvetishëm ose jo, dhe i rrezaton ose jo në përditshmërinë tënde, në mënyrën e të menduarit e të vepruarit.

E së bashku me të, në kujtimet e rrëfimet e Daklit përftohet dukshëm edhe një tjetër profil : ai i ndjenjës së respektit e përkujdesjes për pronën vetjake 


\section{Albanon}

e familjare, për trashëgiminë e brezave. Duke njohur absurditetin e synimit për të formuar "njeriun e ri" që nuk e vlerëson, madje edhe e urren pronën vetjake, duke e konsideruar tragjike zhveshjen e individit/individëve nga prona, duke ngulmuar në pasojat tragjike të marrjes me dhunë të pronësisë e trashëgimisë së brezave, Dakli ngulmon në mënyra të ndryshme përgjatë rrëfimeve te ndjesia e vlera e respektit ndaj saj, si tregues i përftimit më tej të përkatësisë familjare e më gjerë, si përmasë e personalitetit të njeriut.

Në fakt, është kjo një përmasë që e gjetëm si pa e kuptuar pas nëntëdhjetës jo vetëm te ata që erdhën prej një tjetër hapësire ideologjike e politike, por edhe te prindërit tanë me të cilët kishim vite e vite në intimitet e përditshmëri dhe që na e kishin fshehur këtë përmasë, e kishin strukur e mpakur, me siguri në mungesë të shpresës se ndonjë ditë ajo mund t'u duhej; madje vuajtja e tyre për mosshfaqjen e kësaj përmase ka qenë edhe më e madhe se e të afërmve që vinin prej hapësirave të tjera; qe një dhimbje në heshtje, fisnike, por e pangushëllueshme, gjithsesi. Kujtimet e rrëfimet e Daklit na theksojnë pikërisht këto ide, madje na e modelojnë një variant të këtyre përmasave, tejet joshës e domethënës.

\section{Ta gjesh qytetin tënd në kujtime, ashtu siç e do, ashtu siç do të doje ta duan}

I vetëdijshëm që mund të gjejë gjurmë vlerash deri në zona të mugëta të historisë së qytetit të tij, Dakli nuk i synon ato hapësira, sepse i pëlqejnë më shumë përjetimet e gjalla; parapëlqen gjurmën e lënë në vetëdije dhe jo abstraksionet që mund t’i përshtateshin çdo qyteti a qytetërimi tjetër; parapëlqen konkreten, ndaj rrëmon e gjen fakte e ndodhi, ndaj përmallohet e proteston, ndaj është i dashuruar e kritik, e hera-herës vesh edhe mantelin e historianit, të sociologut a kulturologut.

Në kujtesën e tij, Dakli kërkon me ngulm imazhe të pazbehura të kalasë, një gjurmë te bedenat, te rrugët, te pazari; një shenjë të shkollës, të bashkisë, të prefekturës...; një gjurmë të trëndafilave erëmirë, të karafilave, të jalldyzëve, të kanilqyqeve... diçka i kishte mbetur në mendje për një lule si gojasllan, ose një tjetre si lulenishte, dorëzonjë a menekshe... janë të gjitha këto çka kërkon rrëfimtari, por po aq me ngulm i kërkon edhe lexuesi, që po ashtu vihet në kërkim të gjurmëve dhe ndien thirrjen e brendshme: ku është qyteti im?

Jeta në Itali për gati pesëdhjetë vjet dhe pamundësia për ta vizituar herë pas here qytetin e lindjes ia ka shtuar Daklit ndjeshmërinë ndaj përkatësisë 
familjare e qytetare; sa më shumë ndiente trysninë e natyrshme për asimilim në mjedisin italian (të cilin e adhuronte jo pak, të cilin e donte me pasion, në të cilin kishte dashuruar, kishte krijuar një familje të lumtur e një karrierë profesionale të shkëlqyer, që s'mund ta bënte atje - në vendlindje), aq më shumë ndiente t’i kundërqendronte në mënyrë të pavetëdijshme një ndjesi kundërshtie, ose më mirë, ndjesia e një pranie që edhe ashtu e fshehur, e fjetur nuk mënon të ruajë diçka thelbësore, diçka tënden mirëfilli, të patjetërsueshme, të paasimilueshme; e në vetëdije e kujtesë vijonte të kërkonte të shihte sërish kacafytjen e dy rosakëve pendëndritur diku aty në kanalin pranë bedenit të kalasë, shfaqjen e papërsëritshme të liqenit të Belshit që si organizëm i gjallë reagon edhe kur brendësive të tij një peshk, si "sovran" i atyre ujërave noton thellësive dhe tronditja ndjehet si lëkundje shkaktuar vërtet prej sovranit deri në sipërfaqje, përballjen dhe hijeshinë e përplasjes së kuajve që atje fushave të Myzeqesë ua kalojnë edhe pikturave të piktorit italian, Aligi Sassu (1912-2000); kërkon sërish të përjetojë pengesën dhe pamundësinë për ta parë, në atë rrugicën e ngushtë (ndoshta edhe ajo përmasë e kursyer ia shtonte romanticitetin) vajzën e ëndrrave fëminore, të dëgjonte sërish orkestrantët që ndërsa akordonin veglat me zhurmë e bujë dukej se grishnin të pranishmit të afroheshin, të tregoheshin të vëmendshëm e t’ia merrnin këngës më tej nën tingujt e orkestrës; e sidomos, të ritakonte mësuesit (a do mundej vërtet ta përqafonte sërish mësues Ahmetin (Duhanxhiun) e t’i falte gjithë ato emocione që i kishin ngjallur fjalët e tij, dashuria e tij përgjatë githë jetës? Përse të mos e kishte mundësinë e shprehjes së kësaj mirënjohjeje, këtij adhurimi? A nuk do të kishte pengje pothuaj të njëjta edhe për të afërmit? Për Petritin, për Temin... Në cilën hapësirë do t’ $i$ gjente ato sërish, përveçse në atë të mallit? Ç’mund të përjetonte tjetër me pafuqinë e ndryshimit të asaj që shkoi dhe tragjikisht ndau botët, hapësirat, përveç se të përmallohet dhe t’ia shtojë përmasën kësaj ndjenje duke e ndarë atë me lexuesin/-it (më së paku, ja një mënyrë e intensifikimit të shkallës së rritjes së përmasës së përmallimit).

Duket se gëlojnë natyrshëm këto pyetje në mendjen e një njeriu që kishte eksploruar dhe që ishte endur në të tjera hapësira, me të tjera ligjësi të ecurisë në kohë; dhe vjen prej atyre hapësirave dhe kërkon atë çka gjithnjë e mbante lidhur me vetëqenien: kërkon gjurmët e fëmijërisë, të rinisë, të përkatësisë si hapësirë gjeografike e humane. E duke kërkuar këto gjurmë, në fakt, nuk kërkonte realisht atë kohë, atë mjedis, atë realitet (edhe në rastin më ideal të ruajtjes, ai realitet ndoshta nuk do ta ngushëllonte, sepse ishte tashmë edhe ai që kishte ndryshuar), por ai realitet do të ishte i vlefshëm si simbolikë, për ato 


\section{Albanon}

vlera që nxisin këtë përmallim. Është në natyrën e njeriut ta plotësojë përmes përfytyrimeve, imagjinatës, projeksionit të së dëshirueshmes realitetin, edhe kur vëren që tufani, shtërngata, ngrica, acari mund të ketë tharë, shkulur a zhbërë gjithçka të bukur në një kopsht a korije, në një lidhje dashurore a miqësore; duke patur përparësinë e ruajtjes në kujtesë, njeriu ka aftësinë e "krijimit" të botëve; dhe botët e së mirës, veçse e ndihmojnë atë të bëhet edhe vetë më i mirë, të përparojë e kuptojë më shumë.

\section{Një shpirt i ndjeshëm kërkon natyrshëm të shprehet bukur; një qenie e përmalluar kridhet natyrshëm në histori, në traditë...}

Feks ngulmuese përgjatë gjithë rrëfimeve aftësia rrëfyese e Daklit, duke përftuar hera-herës pasazhe që e ke të vështirë të mos ua atribuosh një dore të sigurt në rrëfimtari; e përgjatë rrëfimit ato shfaqen pa pretendime, natyrshëm, organikisht me frymëzimin e ngjyer në një dashuri pa kufi për vendlindjen; hera-herës rrëfyesi imponohet me mantelin e historianit mbi shpatulla, që endet ngeshëm dhe i sigurt në hapësira shekujsh dhe kontinentesh; herë të tjera rrëfyesi shfaqet me mantelin e sociologut mbi supe, e në këto raste është i pamëshirshëm në interpretimin e dukurive sociale, me synimin e objektivitetit më të thekshëm që të mundëson distanca nga kontekstet tejet të ideologjizuara që e turbulloi vështrimin e jo pak sivëllezërve të brezit të tij; e po ashtu, në hulli edhe më të qeta rrëfyesi shihet lehtazi të endet me veshjen e sjelljet fisnike të qytetarit dhe familjarit, kritikut dhe ëndërrimtarit, idealistit, por edhe pragmatikut, e në tërësi duket se përvijohet portreti që ka të dukshme fizionominë e atyre idealistëve që me ngulm po përvijohej si produkti i parë i marrëdhënieve borgjeze që po vendoseshin jo pa vështirësi në kontekstin e shoqërisë shqiptare në dhjetëvjeçarët e parë të shekullit XX; por që pësoi goditje dhe ndërprerje të dhimbshme, që shkaktoi një plagë që veçse malcohej për gati 50 vjet; dhe që s'mund të mbyllet e shërohet lehtë.

E gjuha e mallit, e dashurisë, e ndjenjave humane e tejkalon ngërçin që mund të shfaqë përkatësia e fjalëve në një gjuhë të caktuar; ato mund të jenë paraprakisht në italisht, në frëngjisht, siç mund të jenë edhe në shqip, por në çdo rast janë të pajisura me domethënien më të përzgjedhur, sepse burojnë nga përjetime të ndjera humane. Ndaj edhe pse të shkruara më të shumtat në italisht (kërkues ndaj vetes, i pakënaqur nga rrëfimet e shkruara paraprakisht e pjesërisht ose të plota në shqip, ai është kujdesur që t’i shkruajë sërish në italisht, duke e pasur më të lehtë të ndihmohet nga fëmijët e tij për t’ia 
redaktuar), kujtimet e Daklit ruajnë të njëjtën shprehësi edhe në shqip, të njëjtën bukuri, sepse janë pikërisht të mbrujtura me atë dashuri.

Është tejet joshës përshkrimi i natyrës me të tillë poeticitet, që është domethënës për çdo rrëfimtar a poet, por me sa duket është i natyrshëm dhe i zakontë në një brez intelektualësh të brezit të Daklit, që ishin kultivuar të vërenin natyrën, e për më tepër të poetizonin në të shprehur raportin me të; ja me ç’frymëzim vendoset ai përballë natyrës: «... duket se kryesisht në perëndim të diellit, nga njëra anë mëllenjat frymëzohen nga panorama e veçantë e majave ngjyrëtrëndafili të hapur e maleve, nga pyjet me ngjyrë të gjelbër të thellë dhe nga livadhet plot bar të mbuluar nga një vello e pakapshme drite të praruar; dhe, nga ana tjetër, nxiten prej këtij frymëzimi që të përhapin sa më shumë të jetë e mundur meloditë e tyre të ëmbla dhe të shumëllojshme që të kënaqin edhe krijesat e tjera të natyrës që i dëgjojnë. Dhe këndojnë, këndojnë me zërin e tyre si tingujt e një fyelli, deri në rënien e mbrëmjes: ç’ëmbëlsi'» Vetëm nga një shpirt i dashuruar vërtet me atë qytet mund të burojë një poeticitet i kësaj natyre, me fjalë që nuk vijnë prej mendjes e kujtesës, por prej shpirtit dhe zemres: «Shkumbini rridhte drejt detit si një gërshet $i$ trashë $i$ çrregullt shumëngjyrësh dhe zhdukej nga shikimi i përpirë nga të njëjtat kodra. Në rrëzë të Godoleshit, shumë afèr, aq sa zërat mund të dëgjoheshin, dukej pastër Elbasani.»

\section{Dhimbja nuk është gjithsesi ngushëllim, kur fisnikëria përulet përpara harbutllëkut}

Vërehet në kujtimet e Daklit një pamje tejet humane, e brishtë dhe joshëse e asaj pjese të jetës që lidhet me borgjezinë shqiptare të sapolindur e në zhvillim e sipër në ato vite të fëmijërisë e rinisë së tij; po kultivohej me përkujdesjen më të madhe në ato mjedise familjare interesimi për shkollim e edukim i fëmijëve që do të duhej të zhvillonin në një mënyrë të re atë vend të prapambetur, por të bukur e idilik; e sidomos ta zhvillonin me ritme të tjera, shumë më të shpejta, për të fituar kohën e humbur. Një dëshmi pa censurë, pa paragjykime, kjo e Daklit; një dëshmi përfaqësuese e një brezi, por pa retushimin që i impononte koha bashkëkohësve të autorit në vendin e tij. Përftohet natyrshëm në rrëfimet e Daklit një ndjesi respekti e pafund për familjen, mjedisin e marrëdhëniet familjare, një respekt, adhurim e dashuri pa kushte sidomos për nënën dhe prindët që buron nga aktet e sakrificës së tyre si bindje, madje edhe si instinkt i vijimësisë së jetës; e mbushur me këtë devocion është përvoja e familjes së tij, ku nëna përkujdeset e konsideron të vetët jo vetëm fëmijët e saj të shumtë, por edhe ata të kunatit të saj të ve, 


\section{Albanon}

madje edhe një jetim fatkeq, prindët e të cilit vdesin në një aksident; është një përballje dinjitoze e rrëfimtarit me institucionin e mëmësisë, i respektuar, i kultivuar e nderuar nga tradita shqiptare, e po aq nga feja a fetë, nga njerëzit e thjeshtë a nga intelektualët; nga përvojat jetësore... institucion i përftuar si përvojë, i respektuar pikërisht se është produkt i tillë. Kemi përballë në rrëfimin e Daklit një pasqyrë ku mund të shohim atë çka nuk duhet ta humbim, atë çka meritojmë a duhet ta meritojmë ta kemi: respektin për nënën e familjen, respektin për përkatësinë, për veten.

Nga ana tjetër, duke synuar të mbetet në rrjedhat e një rrëfimi sa më intim, Dakli i shmanget me vetëdije disa treguesve që defaktorizohen kur futen në kallëpet e klisheve dhe propagandës, edhe pse bartin të vërteta dhe vlera (Elbasani, si djep $i$ arsimit, vatër e urtësisë, mirësisë e bamirësisë...); duket se Daklit i dhemb entuziazmi fals, kur patriotizmin kërkon ta imponosh pa patriotë, respektin për dijen, pa respektin për të diturit, vlerësimin e bamirësisë, duke torturuar e vrarë bamirësit, nxitjen gjoja të intelektualizmit, duke gjymtuar elitën intelektuale; ai parapëlqen ta shohë patriotizmin aty ku shfaqet dhe tek ata që e shfaqin, dijen te të diturit dhe te sakrifica e familjeve për t'i mundësuar fëmijëve që të bëhen të tillë, bamirësinë të lidhur me bamirësit dhe intelektualizmin të lidhur me elitën intelektuale që përftohet me aq mund e sakificë; ndaj ai nuk ka nevojë për klishetë, por i drejtohet rrjedhës më të qetë të kujtimeve dhe fakteve që janë realisht pranë tij. E gjithsesi, në rreshta e mes rreshtave, pas dhimbjes e përmallimit, pas adhurimit dhe kritikës, pas entuziazmit dhe skepticizmit, pas modestisë dhe vetëpërmbajtjes ka sidomos një mesazh : vlerat përftohen në kontekste të vlerta: vendlindja është e dashur vetëm në një kontekst të tillë ; kur vlerat do të kërkohen jashtë këtij konteksti, e keqja, edhe e pavlerësuar në atë çast, do të vrasë edhe me jehonën që përzgjatet, të cilën më vonë është e vështirë që ta shmangësh.

Për më tepër, mbetet gjithnjë rreziku që në një mjedis të urtë e tolerant, që po hynte tashmë në hullinë e qytetërimit, individi a individët e zhveshur nga vlerat shfaqen a vijnë në këtë mjedis, përfitojnë nga ajo butësi e tolerancë, e zhbëjnë pastaj atë qytetërim, i njollosin ato vlera. Historia e qytetit lëngon prej plagëve të tilla. Prirja a fryma e respektimit të bujtësit, ardhësit, qytetëruese si prirje në çdo kohë, në kohë të vështira të qytetit, kur politika, ideologjia e rrit zjarrminë dhe ethet e pushtetit, rrit po ashtu shpërfilljen ndaj vlerave; madje kjo shpërfillje imponohet si rregull, absurdi arrin kuota tragjike: bujtësi, ardhësi, të cilit me mirësjellje e tolerancë i ke bërë vend, ke kërkuar ta bësh pjesë të vlerave më qytetëruese që në vijimësi janë kultivuar 
duke shpresuar përftim të dinjitetit, të kërkon, me vrazhdësi e harbutllëk madje, të të lërë pa vend, të të shkulë, të të çrrënjosë, të të zhbëjë, duke t'u imponuar në emër të disa parimeve po ashtu të mbrapshta që u shkojnë përshtat mjediseve primitive prej të cilave po ashtu buron harbutllëku. Dhe kjo histori mund të vazhdojë, nëse fryma qytetëruese nuk përballet me to, duket se nënkupton dhimbja fisnike e Daklit... dhe koha duket se i jep të drejtë. Letrat e ngjitura në derën e së vetmes dhomë që familjes Dakli i ishte lënë për mëshirë, pas dëbimit të parë nga shtëpia e vet, prona e vet, bumbum-et (Bum-bum-bum, kulakët në bodrum! - këtë mesazh gjente nëna e tij e mjerë pas derës çdo mëngjes ndërsa ishte rikthyer në të vetmen dhomë që i kishin lënë pa zaptuar bujtësit, që sërish donin ta zbonin), që dukej se vinin qysh nga mesjeta, janë një padi simbol ku dhimbja e Daklit flet më shumë se çdo thirrje, çdo britmë a klithmë; është një dhimbje që s'ka ngushëllim; është dhimbje që s'ka kohë; është dhimbje që ishte e besueshme dje, është dhimbje e besueshme sot e në çdo kohë; është dhimbje që paralajmëron infeksion, çrregullim të funksionimit të trupit të shoqërisë të cilin ai qytet e toleroi, nuk ia vlerësoi rrezikun, e toleron me fisnikëri, për të keqen e tij.

Intuita e drejtonte po ashtu t’i kundërqëndronte idesë joshëse për barazi në mirëqenie, por që do të çonte në barazi në skamje që do të sillte një rend i ri dhe ideologji e re, entuziazëm që kishte angazhuar shumë miq e shokë të tij e të brezit të tij të cilët sakrifikuan, madje dhanë edhe jetën për atë ideal; dhe në kushtet e zbatimit të një regjimi diktatorial, më së shumti qenë viktimat ndër të parat të hipokrizisë që mbizotëroi. Pa bujë dhe pa triumf, Dakli veçse ndien dhimbje, duke respektuar idealin dhe devocionin e tyre, por duke mospranuar gjithsesi iluzionin dhe hipokrizinë e një regjimi rrënues të vlerave ; respekton edhe pikëpamjet e kundërta me të tijat, por pa humbur kritikën që i buron natyrshëm nga bindjet dhe formimi i tij; vëren zhvillimet në periudha më të gjata dhe mundohet të përgjithësojë e të nxjerrë përfundime, duke qenë gjithnjë sa më i vërtetë e kritik me veten, e po ashtu edhe me atë çka s'mund ta pranojë.

Në çastet e meditimeve a reflektimeve të sinqerta, Dakli e ndien se endet në një terren ku do të hasë një sërë pengesash, sidomos edhe mospranime në raste të caktuara; por vijon i qetë në interpretime, sepse i beson sinqeritetit në vështrim, fisnikërisë në sjellje, frymës së mëkuar qysh në fëmijëri në familje dhe në mjedisin qytetar në të cilin u rrit, formimit intelektual të një sistemi arsimor që prirej t’ia ngustonte hapësirat së keqes, hipokrizisë, duke e menduar njeriun bir të natyrës e sajues të fatit të tij. E ky sinqeritet bëhet joshës e tërheqës edhe për atë që mund të qëndrojë në anë të kundërt; shfaqet 


\section{Albanon}

haptas shpresa e Daklit se mund t’i shërbejë në këtë rast edhe lexuesit që mund të rastisë në atë anë të kundërt, të cilit do të dëshironte t'ia shkurtonte distancën me vlerat që Dakli i konsideron të shenjta e të gjithëkohshme.

\section{Në mbyllje}

Kujtimet, rrëfimet me elemente autobiografike e zgjerojnë pra hapësirën e shënimit kur në to përzgjidhen e pasqyrohen të dhëna vetjake e të mjedisit rrethues që bartin peshën e dukurive shumë më të gjera, që bartin dëshira, pasione, veçanti e karakteristika për entitete më të gjera se thjesht një individ, a kontekste shumë më të gjera se thjesht një familje a një qytet; të duash familjen tënde, të afërmit e tu, të adhurosh pa kushte vlerat më të mira të mjedisit ku je rritur, nuk lidhet vetëm me një rast konkret, por është një vlerë universale; drejt saj orientohet e priret natyrshëm lexueshmëria e kujtimeve e rrëfimeve të Daklit.

Kujtimet dhe rrëfimet e tij, duke qenë një ditiramb për vendlindjen, pra një tekst tejet i adresuar në një mjedis familjar e në një qytet të caktuar, për nga patosi që i karakterizon, veçantitë që priren të nxjerrin në pah në lidhje me atë mjedis në kohëra të caktuara, për nga pikëvështrimet në pasqyrim, për nga natyra e interpretimeve në lidhje me treguesit që e ngjizin një vlerë qytetëruese në kohët moderne, për nga stili e etosi i synuar e përftuar, përvijojnë një model që priret t'i shpërthejë kufijtë e një mjedisi familjar e lokal, e të përkojë me çdo prirje për adhurim të përkatësisë, në çdo vend a kohë qoftë. Në një botë të prirur natyrshëm drejt globales e globalizmit, kjo mënyrë këndvështrimi në fakt nuk pengon, por veçse e ndihmon individin a komunitetin të jetë edhe më i plotësuar në endjet e detyruara në hapësirat më globale...; e ky plotësim nuk pret të përftohet përmes traktateve filozofike a sociologjike që do ta zgjonin e nxisnin këtë përkujdesje; në fakt, mjaftojnë edhe copëza të tilla malli si këto rrëfime që të na zgjojnë; e në zgjim, të na vetëdijësojnë sërish për atë çka jemi e si mund të bëhemi më të mirë. 